\title{
Does Monetary Policy Affect Stock Prices and Treasury Yields? An Error Correction and Simultaneous Equation Approach
}

\author{
J. Benson Durham* \\ Division of Monetary Affairs \\ Board of Governors of the Federal Reserve System \\ Mail Stop 71 \\ $20^{\text {th }}$ and C Streets \\ Washington, DC 20551 \\ j.benson.durham@frb.gov \\ (202) 452-2896
}

\begin{abstract}
This study pursues two addenda to the practitioner and academic on the effect of monetary policy on asset prices. First, this paper applies cointegration theory and, second, relaxes the stringent assumption in the literature that changes in 10-year Treasury yields, stock returns, and changes in the stance of monetary policy are exogenous. Given quarterly data from 1978:Q4 to 2002:Q3, two-stage least squares (2SLS) regressions suggest that changes in the exogenous component of the federal funds rate affect changes in Treasury yields but not stock returns, ceteris paribus. However, this result is sensitive to alternative proxies for the stance of monetary policy. Also, little evidence suggests that monetary policy responds to the exogenous components of changes in financial asset prices.
\end{abstract}

\footnotetext{
* Without implication, the author thanks Antulio Bomfim, Jim Clouse, Darrel Cohen, Brian Madigan, Athanasios Orphanides, and Brian Sack for helpful comments. The views expressed in this paper do not necessarily reflect those of the Board of Governors of the Federal Reserve System or any member of its staff.
} 


\section{Introduction}

A large practitioner and academic literature examines the effect of monetary policy on asset prices. Several studies address the impact of monetary policy surprises on daily or intraday stock returns, for example, while fewer consider longer-run effects on equity prices and Treasury yields. This research question has clear implications for both financial market participants and central bankers. With respect to the former, the subject is of course germane to the broader issue of empirical asset pricing, and practitioners spend considerable resources following (prospective) monetary policy developments. Regarding the latter, the effect of monetary policy on equity prices and interest rates is relevant to several possible transmission mechanisms from central bank actions to the real economy. For example, the Federal Reserve controls the federal funds rate, which purportedly affects market-determined interest rates and asset prices and, in turn, real variables through various possible investment and consumption channels.

This paper pursues two addenda to previous studies on the effect of monetary policy on stock prices and 10-year Treasury yields. First, the empirical literature, particularly regarding policy transmission through the stock market, underutilizes error correction methodology. The basic general intuition behind cointegration theory is that certain economic variables should not diverge substantially in the long run. While such variables can drift apart in the short run, economic forces eventually bring them together again (Granger, 1986, p. 213). An error correction specification of stock prices and interest rates is perhaps particularly appealing with respect to monetary policy, which should have transitory effects on asset prices. The long- and short-run equations of a basic error correction model follow

$$
\mathrm{Y}_{\mathrm{t}}^{*}=\beta_{0}+\beta \mathbf{X}_{\mathrm{t}}+\mathrm{e}_{\mathrm{t}}
$$


and

$$
\Delta \mathrm{Y}_{\mathrm{t}}=\alpha_{0}+\alpha_{1} \Delta \mathbf{X}_{\mathrm{t}}+\alpha_{2} \Delta \mathbf{Z}_{\mathrm{t}}+\alpha_{3} \mathrm{M}_{\mathrm{t}}-\alpha_{4} \mathrm{e}_{\mathrm{t}-1}+\mu_{\mathrm{t}}
$$

respectively, where $\mathrm{Y}$ is the dependent variable, $\mathbf{X}$ is a set of explanatory variables in both equations, $\mathbf{Z}$ is a set of variables that have transitory effects, $M$ is a proxy for the stance of monetary policy, ${ }^{1}$ and $\mathrm{e}_{\mathrm{t}-1}$ is the error correction term.

Second, previous studies of the response of asset prices over longer horizons to monetary policy assume that stock prices, interest rates, and central bank policy are exogenous. But, asset prices such as stocks and Treasury securities might be simultaneously determined, and asset prices contain data about expectations for inflation and real activity that might, in turn, inform monetary policy decisions. Therefore, this paper uses the error correction framework and treats short-run changes in stock prices and Treasury yields, as well as the stance of monetary policy, endogenously. Cointegration methodology is perhaps particularly useful in this regard, as the error correction terms usefully instrument for the endogenous variables.

In general, these data indicate that monetary policy has somewhat limited impact on financial asset prices. In particular, the exogenous component of the nominal federal funds rate is a statistically significant determinant of 10-year Treasury yields, ceteris paribus, but other proxies for the stance of monetary policy do not corroborate this finding. Moreover, few data suggest that monetary policy responds to changes in asset prices. Some evidence suggests that the exogenous component of 10-year Treasury yields correlates positively with the likelihood of policy tightening episodes, but this result is also sensitive to proxy selection.

\footnotetext{
${ }^{1}$ As noted below, hypotheses consider both the level and first difference of monetary policy proxies.
} 
The next section reviews the literature on the longer-run effects of central bank policy on stock returns and Treasury yields and presents the cointegration regression and unit root tests for the long-run models of stock prices, interest rates, and monetary policy. Section 3 includes the models for short-run dynamics, which follow simple instrumental variable (IV) techniques that relax the assumption that financial asset price changes and monetary policy are exogenous. Section 4 concludes.

\section{Error Correction Models of Stock Prices, Interest Rates, and Monetary Policy}

Before examining the short-run relations between asset prices and monetary policy, this section focuses on long-run equilibrium models and the time-series properties of the data. The discussion briefly outlines the literature on the effect of monetary policy on asset prices; reports the results from unit root and mean stationarity tests of key variables; presents cointegrating regressions for stock prices, 10-year Treasury yields, and the nominal federal funds rate; and discusses the problem of simultaneity bias.

\subsection{Stock Prices: Previous Literature and Cointegration Theory}

Economists generally posit that restrictive (accommodative) monetary policy leads to lower (higher) stock prices. For example, some researchers argue that changes in monetary policy influence forecasts of market-determined interest rates, the equity cost of capital, and expectations of corporate profitability (Waud, 1970). Others argue that central banks ease (tighten) in responds to economic contraction (expansion), and therefore ex ante required and realized ex post returns rise (fall) (Jensen and Johnson, 1995; Conover et al., 1999a, 1999b). 
Some studies use high frequency data and document a correlation between monetary policy changes and daily or intraday stock returns in the United States (Waud, 1970; Smirlock and Yawitz, 1985; Cook and Hahn, 1988). With respect to the longer-run, Jensen and Johnson (1995) examine monthly and quarterly performance and find that expected stock returns are significantly greater during expansive monetary periods, and Conover et al. (1999a, 1999b) make similar inferences using cross-country data. However, Durham (2001a, 2003) finds that these findings are highly sensitive to alternative proxies for monetary policy; the use of excess as opposed to raw stock returns; and sample selection, as more recent samples do not produce a statistically significant relation.

In general, these time-series models of index returns follow

$$
\Delta S_{t}=\alpha_{0}+\alpha_{1} D_{t}^{\text {local }}+\alpha_{2} J+\varepsilon_{t}
$$

where $\Delta \mathrm{S}_{\mathrm{t}}$ is the $\log$ difference of stock prices, $\mathrm{D}_{\mathrm{t}}$ is a dummy variable equal to one (zero) if prevailing local monetary regime is restrictive (expansive), ${ }^{2}$ and $\mathbf{J}$ is a set of control variables.

This paper extends this literature and, in contrast to (3), follows an error correction specification of stock prices. As Harasty and Roulet (2000) argue, ${ }^{3}$ perhaps cointegration theory is particularly germane to empirical models of stock market behavior - fundamental factors drive market valuation in the long run, but in the short run, the market often substantially diverges from its "fair" or fundamental value. Such short-run deviations are not sustainable, the argument

\footnotetext{
${ }^{2}$ As Section 3 discusses in greater detail, this literature commonly expresses the policy variable in levels and the dependent variable in first differences, which is somewhat problematic.

${ }^{3}$ For an earlier application of cointegration theory to stock prices see Campbell and Shiller (1987).
} 
reasons, and eventually investors arbitrage the gap between fundamental fair value and short-run market trends. ${ }^{4}$

Of course, determination of a fair value for stock prices is highly controversial, but for these purposes, a simple present value model based on the widely cited Gordon-Shapiro formula follows

$$
P_{t}=\frac{D_{t}(1+g)}{I_{t}+\theta-g}
$$

where $D_{t}$ is the current level of dividends, $I_{t}$ is the long-run riskless rate of interest, $g$ is the growth rate of dividends, and $\theta$ is the equity risk premium. Following, Harasty and Roulet (2000), ${ }^{5}$ who do not explicitly focus on the effect of monetary policy, the econometric representation, expressed in logs, replaces dividends with earnings and simplifies the expression of the discount factor. The corresponding empirical model and candidate long-run coingegrating regression is therefore

$$
\mathrm{S}_{\mathrm{t}}=\beta_{0}+\beta_{1} \mathrm{EPS}_{\mathrm{t}}+\beta_{2} \mathrm{I}_{\mathrm{t}}^{10-\mathrm{yr}}+\mathrm{e}_{\mathrm{t}}^{\mathrm{S}}
$$

where $\mathrm{S}_{\mathrm{t}}$ is the log level of the S\&P 500, EPS $\mathrm{t}_{\mathrm{t}}$ is the (log) one-year forward earnings-per-share from IBES, $\mathrm{I}^{10-\mathrm{yr}}{ }_{\mathrm{t}}$ is the 10 -year Treasury yield, and $\mathrm{e}_{\mathrm{t}}^{\mathrm{S}}$ is the error term.

\footnotetext{
${ }^{4}$ The error correction term in (2) usefully addresses a particular shortcoming in (3). Even if accounting-based value measures are included in equation (3), time-series index models cannot adequately incorporate the effect of valuation measures on returns. First differences in, say, the price-to-earnings or price-to-book ratios are problematic in such specifications because changes in these measures are substantially driven by changes in stock prices, the dependent variable. Therefore, (3) cannot control for an important class of key supposed determinant of returns. In contrast, error correction methodology explicitly captures a more general "fair value." The literature largely assesses the predictive power of accounting-based ratios such as price-to-book or price-to-earnings with crosssectional firm-level data (i.e. Fama and French, 1992).

${ }^{5}$ The variable that most closely measures the stance of monetary policy in their short-run regressions is the "relative variation" of short-term interest rates.
} 


\subsection{Stock Prices: Unit Root Tests and the Cointegrating Regression}

Error correction methodology is warranted only if the variables in the model are integrated to the first order, I(1), and can be cointegrated. Following Mehra (1994), the analyses include both unit root and mean stationarity tests. The unit root tests are augmented DickeyFuller (ADF) regressions, and the test for mean stationarity follows Kwiatkowski, Phillips, Schmidt, and Shin (1992) (KPSS). Both tests alternatively assume one- and eight-quarter lags. A variable is non-stationary (stationary) if the null hypothesis of a unit root is not (is) rejected by the ADF test, and if the null hypothesis of mean stationarity is (is not) rejected by the KPSS test. ${ }^{6}$

Table 1 presents the KPSS and ADF tests results for $\mathrm{S}_{t}, \mathrm{EPS}_{\mathrm{t}}$, and $\mathrm{I}_{\mathrm{t}}^{10-\mathrm{yr}}$ from $(5)$ for the quarterly data during 96 quarters (14 years) from 1978:Q4 to 2002:Q3. The results clearly suggest that EPS and $\mathrm{I}^{10-\mathrm{yr}}$ are $\mathrm{I}(1)$ - that is, the ADF tests indicate that the null hypothesis (H0) of a unit root can be rejected for the first difference but not the level of both variables for either lag assumption. ${ }^{7}$ Also, the KPSS tests suggest that the null hypothesis of mean stationarity can be rejected for the level but not for the first difference of both variables. The ADF and KPSS tests also indicate that log stock prices are not stationary - the ADF tests of the level of stock prices indicate that the $\mathrm{H} 0$ of a unit root cannot be rejected, and the KPSS tests suggest that the $\mathrm{H} 0$ of mean stationarity can be rejected for the level but not the first difference under both lag

\footnotetext{
${ }^{6}$ The ADF and KPSS tests do not consider whether these series follow a fundamentally different underlying process - a (cyclical) time series with a break, not a unit root (Perron, 1989, 1997). An alternative test, following Perron (1997), takes into account an unknown break in the mean. This procedure entails the Augmented Dickey-Fuller (ADF) test with a break in the constant term sequentially for all possible break points $b$ per case, as in

$$
\begin{array}{cc}
y_{t}=\mu+\theta D_{t}+\delta D b_{t}+\alpha y_{t-1}+\sum_{i=1}^{k} c_{i} \Delta y_{t-i}+e_{t} \\
t=k+1, \ldots, T ; \quad D_{t}=0(t=k+1, \ldots, b) ; & D_{t}=1(t=b+1, \ldots, T) ; \\
D b_{t}=0(t=k+1, \ldots, b, b+2, \ldots, T) ; & D b_{t}=1(t=b+1)^{6}
\end{array}
$$

where $y$ is variable of interest. If $\mathrm{y}_{\mathrm{t}}$ is stationary with a parameter break, then $\alpha$ should be statistically different from zero. Briefly, the results from this alternative test suggests that none of the variables in Tables 1-3 are I(1) but rather stationary processes with (arbitrary) breaks in the mean.

${ }^{7}$ However, following the method in Perron (1997), about 29 (43) percent of all possible breaks suggest that $\mathrm{I}^{10-\mathrm{yr}}$ is a stationary series with breaks in the parameters given eight (one) lag terms.
} 
assumptions. The ADF tests of $\Delta \mathrm{S}_{\mathrm{t}}$ are somewhat sensitive to lag assumption - inclusion of one [eight] lagged terms suggests that $S_{t}$ is $\mathrm{I}(1)$ [I(2)]. However, again, the level of $S_{t}$ is clearly nonstationary.

Table 4 presents the results from regression (5), the cointegrating regression. As Model (1) indicates, $\beta_{1}$ is safely statistically significant and positive with a coefficient notably greater than unity, and $\beta_{2}$ is similarly statistically significant with the anticipated negative sign and suggests that stock prices fall about 6.5 percentage points with a 100 -basis point increase in interest rates. Therefore, these data suggest that in the long run stock prices are strongly related to anticipated earnings and the level of interest rates. Also, returning to Table 1, the ADF test results indicate that the $\mathrm{H} 0$ of a unit root can be rejected for the residual of this regression, $\mathrm{e}^{\mathrm{S}}$, and the KPSS test suggests that the $\mathrm{H} 0$ of mean stationarity cannot be rejected. This further suggests that $\mathrm{S}_{\mathrm{t}}, \mathrm{EPS}_{\mathrm{t}}$, and $\mathrm{I}_{\mathrm{t}}^{10-\mathrm{yr}}$ can be cointegrated. ${ }^{8}$

Given that $S_{t}, E P S_{t}$, and $I^{10-y r}$ are $I(1)$ and that the series can be cointegrated, short-run regressions might follow

$$
\Delta \mathrm{S}_{\mathrm{t}}=\alpha_{0}+\alpha_{1} \Delta \mathrm{EPS}_{\mathrm{t}}+\alpha_{2} \Delta \mathrm{I}_{\mathrm{t}}^{10-\mathrm{yr}}+\alpha_{3} \mathrm{Z}_{\mathrm{t}}^{\mathrm{S}}+\alpha_{4} \Delta \mathrm{M}_{\mathrm{t}}+\alpha_{5} \mathrm{e}_{\mathrm{t}-1}^{\mathrm{S}}+\mu_{\mathrm{t}}
$$

where $\mathbf{Z}^{\mathbf{S}}$ includes additional variables that have transitory effects, $\Delta \mathrm{M}$ is a proxy for the change in the stance of monetary policy, and $\mathrm{e}^{\mathrm{S}-1}$ is the error correction term. $\mathbf{Z}^{\mathrm{S}}$ comprises several factors, anomalous or otherwise, that previous index-level studies suggest correlate with stock market returns (Durham, 2001b). These include three price history variables - one-month lagged

\footnotetext{
${ }^{8}$ The sequential estimation of (1) and (2) or (5) and (6) follows Engle and Granger (1987) as well as Harasty and Roulet (2000) and differs from the method in Johansen (1988). This two-step method does not determine whether there is a unique cointegrating relation or a complex linear combination of all distinct cointegrating vectors in the system. As Harasty and Roulet (2000) note, one advantage of the two-step method is that it directly reflects the intuition behind long-run value and short-run deviations. Moreover, some studies (Campbell and Perron, 1991) suggest that the Johansen-Juselious (1990) method is highly sensitive to mis-specifiaction.
} 
return, three- through 12-month lagged return (Jegadeesh, 1990), and the one-year lagged return (De Bondt and Thaler, 1985) - and proxies for calendar effects - including dummy variables for the January (Haugen and Lakonishok, 1987) and September (Siegel, 1998) effects.

The problem at this juncture, however, is that $\Delta \mathrm{S}_{\mathrm{t}}, \Delta \mathrm{I}^{10-\mathrm{yr}}{ }_{\mathrm{t}}$, and $\Delta \mathrm{M}_{\mathrm{t}}$ are perhaps determined simultaneously, and an estimate of (6) should include instruments for $\Delta \mathrm{I}^{10-\mathrm{yr}}$ and $\Delta \mathrm{M}_{\mathrm{t}}$. Therefore, the remainder of this section discusses the identification of $\Delta \mathrm{I}^{10-\mathrm{yr}}{ }_{\mathrm{t}}$ and $\Delta \mathrm{M}_{\mathrm{t}}$.

\subsection{Treasury Yields: Previous Literature and Cointegration Theory}

Surprisingly few studies focus on the economic forces that determine the overall level of interest rates (Sargent, 1969; Howe and Pigott, 1991; Mehra, 1994). But, Sargent (1969) provides a useful framework for modeling the nominal interest rate, $\mathrm{r}^{\mathrm{n}}{ }_{\mathrm{t}}$, which is comprised of a real equilibrium component, $\left(\mathrm{r}_{\mathrm{t}}^{\mathrm{e}}\right)$; inflation expectations, $\left(\mathrm{r}_{\mathrm{t}}^{\mathrm{n}}-\mathrm{r}_{\mathrm{t}}^{\mathrm{m}}\right)$, expressed as the difference between nominal and real market rates; and a term that measures the (expected) stance of monetary policy, $\left(\mathrm{r}_{\mathrm{t}}^{\mathrm{m}}-\mathrm{r}_{\mathrm{t}}^{\mathrm{e}}\right)$, expressed as the difference between the real market rate and the equilibrium real interest rate. This sum follows

$$
r_{t}^{n}=\left(r_{t}^{e}\right)+\left(r^{n}{ }_{t}-r^{m}{ }_{t}\right)+\left(r^{m}{ }_{t}-r^{e}{ }_{t}\right)
$$

The first term of (7), $\mathrm{r}_{\mathrm{t}}^{\mathrm{e}}$, is the equilibrium real rate that equates ex ante (private) savings with investment and the government deficit (as well as the capital account in an open economy). Investment, INV, and private savings, $\mathrm{SAV}^{\mathrm{P}}{ }_{\mathrm{t}}$, follow

$$
\mathrm{INV}_{\mathrm{t}}=\mathrm{a}_{0}+\mathrm{a}_{1} \Delta \mathrm{Y}_{\mathrm{t}}-\mathrm{a}_{2} \mathrm{r}_{\mathrm{t}}^{\mathrm{e}}
$$




$$
\mathrm{SAV}_{\mathrm{t}}^{\mathrm{P}}=\mathrm{b}_{0}+\mathrm{b}_{1} \mathrm{Y}_{\mathrm{t}}+\mathrm{b}_{2} \mathrm{r}_{\mathrm{t}}^{\mathrm{e}}
$$

where $\mathrm{Y}$ is real income. Equation (8) is an accelerator-investment equation with interest rate effects, and (9) is a Keynesian savings function.

In a closed economy equilibrium, which Sargent (1969) and Mehra (1994) consider, the government surplus equals the excess of investment over private savings. In an open economy, the government surplus equals the excess of investment and net exports over private savings, and therefore $r_{t}^{e}$ solves

$$
\mathrm{SAV}_{\mathrm{t}}^{\mathrm{G}}=\left(\mathrm{INV}_{\mathrm{t}}+\mathrm{NX}_{\mathrm{t}}\right)-\mathrm{SAV}_{\mathrm{t}}^{\mathrm{P}}
$$

where $S A V^{G}{ }_{t}$ is the government surplus to GDP, and NX is net exports to GDP. ${ }^{9}$ Substituting (8) and (9) into (10) produces an expression for the equilibrium real interest rate, as in

$$
r_{t}^{e}=\frac{1}{b_{2}+a_{2}}\left[\left(a_{0}-b_{0}\right)+a_{1} \Delta Y_{t}-b_{1} Y_{1}-S A V_{t}^{G}+N X_{t}\right]
$$

The government deficit (negative government savings), real income growth, and trade surpluses raise the demand for funds and hence drive up $r_{t}{ }_{t}$, while a higher level of output generates a larger volume of savings and hence reduces $\mathrm{r}^{\mathrm{e}}{ }_{\mathrm{t}}$.

The second term of (7) is the gap between nominal and real interest rates, which arises due to anticipated inflation following

$$
\mathrm{r}_{\mathrm{t}}^{\mathrm{n}}-\mathrm{r}_{\mathrm{t}}^{\mathrm{m}}=\mathrm{k} \pi_{\mathrm{t}}^{\mathrm{e}}
$$

where $\pi^{e}$ is anticipated inflation.

\footnotetext{
${ }^{9}$ The hypothesized sign for NX based on the identity is somewhat counterintuitive. For example, persistent trade surpluses can lead to a depreciation of the real exchange rate, which would necessitate a risk premium on domestic rates to attract investors.
} 
The third term of (7) is the deviation of the real market rate from the equilibrium rate, $\mathrm{r}_{\mathrm{t}}^{\mathrm{m}}$ $-r_{t}^{e}$. This interest rate gap arises in part from monetary policy, as changes in the money supply or some other monetary policy tool affect the demand and supply curves for funds following

$$
\mathrm{r}_{\mathrm{t}}^{\mathrm{m}}-\mathrm{r}_{\mathrm{t}}^{\mathrm{e}}=-\mathrm{h}_{\mathrm{i}} \mathrm{RM} \mathrm{M}_{\mathrm{t}}
$$

where RM is a proxy for the real stance of monetary policy. More accommodative (restrictive) monetary policy drives the market rate down (up) with respect to the equilibrium real rate.

Substituting (11), (12), and (13) into (7) produces a candidate cointegrating equation,

$$
\mathrm{r}_{\mathrm{t}}^{\mathrm{n}}=\beta_{0}+\beta_{1} \pi^{\mathrm{e}}-\beta_{2} \mathrm{RM}_{\mathrm{t}}-\beta_{3} \mathrm{SAV}_{\mathrm{t}}^{\mathrm{G}}-\beta_{4} \mathrm{Y}_{\mathrm{t}}+\beta_{5} \Delta \mathrm{Y}_{\mathrm{t}}+\beta_{6} \mathrm{NX}+\varepsilon,
$$

which suggests that the nominal bond rate depends on anticipated inflation, changes in the real stance of monetary policy, the (stock of the) government budget balance, changes in income, the level of income, and net exports. However, some of these variables are possibly $\mathrm{I}(0)$ and do not belong in the cointegrating relation.

\subsection{Treasury Yields: Unit Root Tests and the Cointegrating Regression}

Table 2 presents the ADF and KPSS tests for proxies for each of the right-hand-side variables in (14). Following Howe and Pigott (1991), the proxy for inflation expectations is the trailing 3-year average of (annualized) quarterly inflation. ${ }^{10}$ Following Mehra (1994), the proxy for the real stance of monetary policy is the real federal funds rate. Total marketable federal

\footnotetext{
${ }^{10}$ Results using the Michigan survey's one-year ahead inflation expectations are available on request. The trailing 3 -year average used in Tables 5-8, however, explains considerable more variance in nominal interest rates that the survey data.
} 
government debt (to GDP) proxies $\mathrm{SAV}^{\mathrm{G}} .{ }^{11}$ Also, given the positive correlation between forward-looking EPS and income, the log of EPS proxies $Y,{ }^{12}$ and the excess of exports over imports, divided by GDP, measures NX.

The results suggest that $\mathrm{I}^{10 \text {-yr }}$ (from Table 1), EPS (from Table 1), and NX are I(1). The $\mathrm{H} 0$ of mean stationarity can (cannot) be rejected, and the H0 of a unit root cannot (can) be rejected for the level (first difference) of these variables. The tests also suggest that $\pi^{\mathrm{e}}$ is I(1), and this result contradicts the view that inflation moves within a (target) range. ${ }^{13}$

Also, the data indicate that $\mathrm{SAV}^{\mathrm{G}}$ is non-stationary, but some tests suggest that $\mathrm{SAV}^{\mathrm{G}}$ might be I(2) - the ADF test with eight lags suggests that the $\mathrm{H} 0$ of a unit root cannot be rejected, and the KPSS with one lag test indicates that the H0 of mean-stationarity can be rejected for $\triangle \mathrm{SAV}^{\mathrm{G}}$. Some tests suggest that the level of the real effect funds rate is stationary the ADF test with one lag suggests that the $\mathrm{H} 0$ of a unit root can be rejected, and the KPSS tests that includes eight lags indicates that the $\mathrm{H} 0$ of mean stationarity cannot be rejected. Therefore, the stationary variables from (14) - RM and $\triangle \mathrm{EPS}$ - are not included in the cointegrating regression, which therefore follows

$$
\mathrm{I}_{\mathrm{t}}^{10-\mathrm{yr}}=\beta_{0}+\beta_{1} \pi_{\mathrm{t}}^{\mathrm{e}}-\beta_{2} \mathrm{SAV}_{\mathrm{t}}^{\mathrm{G}}-\beta_{3} \mathrm{EPS}_{\mathrm{t}}+\beta_{4} \mathrm{NX} \mathrm{X}_{\mathrm{t}}+\mathrm{e}_{\mathrm{t}}^{\mathrm{I10-yr}}
$$

\footnotetext{
${ }^{11}$ Results using the government deficit flow, which perhaps more closely follows the loanable funds model outlined in Section 2.3 are available on request.

${ }^{12}$ Regressions that include the level and first difference of actual quarterly real output are available on request. However, in the context of 2SLS, these specifications suggest that $\Delta \mathrm{Y}$ identifies changes in bond prices, while $\Delta \mathrm{EPS}$ identifies changes in stock prices. However, Y and EPS both seem broadly related to the overall level of economic activity.

${ }^{13}$ But, following Perron (1997), $\pi^{\mathrm{e}}$ is stationary with breaks in the mean. About 25 (31) percent of all possible break points suggest that $\pi^{\mathrm{e}}$ does not follow a unit root given eight (one) lag terms.
} 
where $\mathrm{e}^{\mathrm{I} 10-\mathrm{yr}}{ }_{\mathrm{t}}$ is the error term.

According to Model 2 in Table 4, the estimates are largely consistent with the hypotheses, as $\beta_{1}, \beta_{2}$, ${ }^{1415}$ and $\beta_{3}$ have the expected signs and are safely statistically significant. However, the coefficient for NX, $\beta_{4}$, is negative and safely significant, perhaps consistent with an alternative hypothesis that higher levels of net exports lead to currency appreciation and lower domestic interest rates. In addition, returning to Table 2, the residuals from this cointegrating regression are $\mathrm{I}(0)$ - the $\mathrm{H} 0$ of mean stationarity cannot be rejected but that the unit root hypothesis can be rejected.

Given that the independent variables in (15) are I(1), the corresponding model of shortrun dynamics follows

$$
\Delta \mathrm{I}_{\mathrm{t}}^{10-\mathrm{yr}}=\alpha_{0}+\alpha_{1} \Delta \pi_{\mathrm{t}}^{\mathrm{e}}-\alpha_{2} \Delta \mathrm{SAV}_{\mathrm{t}}^{\mathrm{G}}+\alpha_{3} \Delta \mathrm{EPS}_{\mathrm{t}}+\alpha_{4} \Delta \mathrm{NX}_{\mathrm{t}}-\alpha_{5} \Delta \mathrm{S}_{\mathrm{t}}+\alpha 6 \Delta \mathrm{Mt}+\alpha_{7} \mathrm{e}_{\mathrm{t}-1}^{\mathrm{I} 10-\mathrm{yr}}+\mu_{\mathrm{t}},
$$

where $\mathrm{e}_{\mathrm{I}-1}^{\mathrm{I} 10-\mathrm{yr}}$ is the error correction term. But again, $\Delta \mathrm{S}_{\mathrm{t}}, \Delta \mathrm{I}^{10-\mathrm{yr}}{ }_{\mathrm{t}}$, and $\Delta \mathrm{M}_{\mathrm{t}}$ are likely determined simultaneously, and the discussion now turns to identification of $\Delta \mathrm{M}_{\mathrm{t}}$.

\subsection{Monetary Policy: The Taylor Rule, Unit Root Tests and the Cointegrating Regression}

A large literature addresses both the descriptive and prescriptive aspects of the "Taylor Rule" for monetary policy (Taylor, 1993), in which central bank policy responds to variations in inflation and output. Very briefly, a very simple econometric representation of the rule follows

$$
\mathrm{M}_{\mathrm{t}}=\beta_{0}+\beta_{1} \pi_{\mathrm{t}}^{\mathrm{e}}+\beta_{2} \psi_{\mathrm{t}}+\mathrm{e}^{\mathrm{M}}{ }_{\mathrm{t}}
$$

\footnotetext{
${ }^{14}$ This result is of course highly germane to the debate regarding the effects of government spending on interest rates. Again, the proxy in this paper is the stock of total marketable federal government debt to GDP, which is not a measure of market expectations of future fiscal balances. 15
} 
where a possible proxy for $M_{t}$ includes the nominal federal funds rate, $\psi_{t}$ is the output gap (the difference between current and potential output), and $\mathrm{e}^{\mathrm{M}}{ }_{\mathrm{t}}$ is an error term.

Again, $\pi^{\mathrm{e}}$ is I(1) according to Table 2, and the ADF and KPSS results in Table 3 indicate that the effective federal funds rate and $\psi$ are also I(1). The result for the output gap is somewhat surprising, as the concept concerns (temporary) deviations from potential output, which presumably by construction revert back to potential (the mean). Therefore, one might interpret (17) as a cointegrating relation only in a strict econometric sense, given that $\psi_{\mathrm{t}}$ is a stationary concept. Nevertheless, Model 3 in Table 4 indicates that $\beta_{1}$ and $\beta_{2}$ both have the expected positive signs and are safely statistically significant. Moreover, some data indicate that $\mathrm{e}^{\mathrm{M}}{ }_{\mathrm{t}}$ is stationary, which suggests that the variables in the simple Taylor Rule specification can be cointegrated. (However, as Table 3 indicates, these results are somewhat sensitive to lag length, as the $\mathrm{H} 0$ of a unit root cannot be rejected given the ADF test with eight lags, and the $\mathrm{H} 0$ of mean stationarity can be rejected given the KPSS test with eight lags.)

The corresponding model of short-run dynamics follows

$$
\Delta \mathrm{M}_{\mathrm{t}}=\alpha_{0}+\alpha_{1} \Delta \pi_{\mathrm{t}}^{\mathrm{e}}+\alpha_{2} \Delta \psi_{\mathrm{t}}+\alpha_{3} \Delta \mathrm{S}_{\mathrm{t}}+\alpha_{4} \Delta \mathrm{I}^{10-\mathrm{yr}}{ }_{\mathrm{t}}+\alpha_{5} \Delta \mathrm{M}_{\mathrm{t}-1}+\alpha_{6} \mathrm{e}_{\mathrm{t}-1}^{\mathrm{M}}+\mu_{\mathrm{t}}
$$

and notably includes $\Delta \mathrm{S}_{\mathrm{t}}$ and $\Delta \mathrm{I}^{10-\mathrm{yr}}{ }_{\text {t, }}$ consistent with the view that financial asset prices might very well inform central bank policy. In addition, the short-run specification includes lagged changes in the federal funds rate to capture possible policy inertia.

Given specification of the cointegrating relations for $S_{t}, I^{10-y r}$, and $M_{t}$, the discussion now turns to estimation of the exogenous components of the endogenous variables.

\section{Short-run Dynamics}


This section examines the short-run dynamics of the first differences in stock prices, Treasury yields, and monetary policy. The discussion outlines the identification of the system of equations; presents the 2SLS results, including the first stage regressions; and briefly examines alternative proxies for the stance of monetary policy.

\subsection{Identification of the 2SLS System}

$\Delta \mathrm{S}_{\mathrm{t}}, \Delta \mathrm{I}^{10-\mathrm{yr}}{ }_{\mathrm{t}}$, and $\Delta \mathrm{M}_{\mathrm{t}}$ can be identified given equations (6), (16), and (18), rewritten as

$$
\begin{gathered}
\Delta \mathrm{S}_{\mathrm{t}}=\alpha_{0}+\alpha_{1} \Delta \mathrm{EPS}_{\mathrm{t}}+\alpha_{2} \Delta \mathrm{I}^{10-\mathrm{yr}}{ }_{\mathrm{t}}+\alpha_{3} \mathrm{Z}_{\mathrm{t}}^{\mathrm{S}}+\alpha_{4} \Delta \mathrm{M}_{\mathrm{t}}+\alpha_{5} \mathrm{e}_{\mathrm{t}-1}^{\mathrm{S}}+\mu_{\mathrm{t}} \\
\Delta \mathrm{I}_{\mathrm{t}}^{10-\mathrm{yr}}=\beta_{0}+\beta_{1} \Delta \pi_{\mathrm{t}}^{\mathrm{e}}-\beta_{2} \Delta \mathrm{SAV}_{\mathrm{t}}^{\mathrm{G}}+\beta_{3} \Delta \mathrm{EPS}_{\mathrm{t}}+\beta_{4} \Delta \mathrm{NX}_{\mathrm{t}}-\beta_{5} \Delta \mathrm{S}_{\mathrm{t}}+\beta_{6} \mathrm{M}_{\mathrm{t}}+\beta_{7} \mathrm{e}^{\mathrm{I} 10-\mathrm{yr}}+\mu_{\mathrm{t}-1} \\
\Delta \mathrm{M}_{\mathrm{t}}=\chi_{0}+\chi_{1} \Delta \pi_{\mathrm{t}}^{\mathrm{e}}+\chi_{2} \Delta \psi_{\mathrm{t}}+\chi_{3} \Delta \mathrm{S}_{\mathrm{t}}+\chi_{4} \Delta \mathrm{I}^{10-\mathrm{yr}}{ }_{\mathrm{t}}+\chi_{5} \Delta \mathrm{M}_{\mathrm{t}-1}+\chi_{6} \mathrm{e}_{\mathrm{t}-1}^{\mathrm{M}}+\mu_{\mathrm{t} .}
\end{gathered}
$$

Specifically, $\mathrm{Z}_{\mathrm{t}}^{\mathrm{S}}$, and $\mathrm{e}_{\mathrm{t}-1}^{\mathrm{S}}$ identify $\Delta \mathrm{S}_{\mathrm{t}} ; \Delta \mathrm{SAV}_{\mathrm{t}}^{\mathrm{G}}, \Delta \mathrm{NX}_{\mathrm{t}}$, and $\mathrm{e}_{\mathrm{t}-1}^{\mathrm{I} 10-\mathrm{yr}}$ identify $\Delta \mathrm{I}^{10-\mathrm{yr}}$; and $\Delta \psi_{\mathrm{t}}, \mathbf{M}_{\mathrm{t}-1}$, and $\mathrm{e}_{\mathrm{t}-1}^{\mathrm{M}}$ identify $\mathrm{M}_{\mathrm{t}}{ }^{16}$ These variables, in addition to $\Delta$ EPS and $\Delta \pi^{\mathrm{e}}$, are the independent variables in the first stage regressions. Following simple 2SLS estimation, the predicted values from the first stage regressions instrument for $\Delta \mathrm{S}_{\mathrm{t}}, \Delta \mathrm{I}^{10-\mathrm{yr}}$, and $\Delta \mathrm{M}_{\mathrm{t}}$ in the second stage regressions.

\subsection{Econometric Results: The Federal Funds Rate}

Table 5 presents the 2SLS regressions using the effective federal funds rate as the proxy for $\mathrm{M}_{\mathrm{t}}$. Models 1, 2, and 3 are the first stage regressions, and Models 4, 5, and 6 are the second stage regressions for $\Delta \mathrm{S}_{\mathrm{t}}, \Delta \mathrm{I}^{10-\mathrm{yr}}$, and $\Delta \mathrm{M}_{\mathrm{t}}$, respectively. Two sets of questions are relevant.

\footnotetext{
${ }^{16}$ Results that do not include $\mathrm{e}_{\mathrm{t}-1}^{\mathrm{M}}$ are available on request.
} 
First, how well do the instruments perform in the first stage regressions? And, second, given the instruments, are the exogenous components of $\Delta \mathrm{S}_{\mathrm{t}}, \Delta \mathrm{I}^{10-y \mathrm{r}}$, and $\Delta \mathrm{M}_{\mathrm{t}}$ statistically significant?

Regarding the first question, Model 1, the first stage regression for $\Delta \mathrm{S}_{\mathrm{t}}$, indicates that one-quarter lagged return is statistically significant and positive, consistent with Harasty and Roulet (2000) but in contrast to the short-run contrarian hypothesis (Jegadeesh, 1990). Also, the dummy variable for the first quarter is statistically significant, at least with 10 percent confidence, broadly consistent with the January effect. Finally, the error correction term, $\mathrm{e}_{\mathrm{t}-1}^{\mathrm{S}}$ is safely statistically significant and suggests that about 19.2 percent of the disequilibrium in the long-run relation is corrected each quarter. None of the other variables that purportedly help identify short-run movements in stock prices are statistically significant, and the exogenous variables together explain about 0.26 percent of the variance in $\Delta \mathrm{S}_{\mathrm{t}}$.

The first stage regression for $\Delta \mathrm{I}^{10-y r}$, Model 2, indicates that $\Delta \pi_{t}^{\mathrm{e}}$ is positive as expected and statistically significant, albeit with 10 percent confidence. Also, consistent with the cointegrating regression, $\Delta \mathrm{NX}_{\mathrm{t}}$ is negative and significant with 10 percent confidence, and $\mathrm{e}_{\mathrm{t}}^{\mathrm{I10-yr}}$ 1 is statistically significant and indicates that approximately 15.7 percent of the disequilibrium is corrected each quarter. The $\mathrm{R}^{2}$ for the first stage regression for $\Delta \mathrm{I}^{10-y r}{ }_{t}$ is 0.33 .

Model 3, the first stage regression for $\Delta \mathrm{M}_{\mathrm{t}}$, indicates that $\Delta \pi_{\mathrm{t}}^{\mathrm{e}}$ and $\Delta \psi_{\mathrm{t}}$ are statistically significant with the expected positive signs, and $\mathrm{e}^{\mathrm{M}}{ }_{\mathrm{t}-1}$, which is safely statistically significant, suggests that about 30.9 percent of the Taylor Rule disequilibrium is corrected each quarter. The exogenous variables explain about 42 percent of the variance in $\Delta \mathrm{M}_{\mathrm{t}}$.

With respect to the second question, Model 4 is the second stage regression for $\Delta \mathrm{S}_{\mathrm{t}}$ and follows (6) but with the exogenous components for $\Delta \mathrm{I}^{10-y r}$ and $\Delta \mathrm{M}_{\mathrm{t}}$. Although the exogenous components for $\Delta \mathrm{I}^{10-y r}$ and $\Delta \mathrm{M}_{\mathrm{t}}$ have the expected negative signs, the estimates are not 
statistically significant. Therefore, the system of equations suggests that changes in the stance of monetary policy and changes in interest rates do not affect stock returns, ceteris paribus. Rather, Model 4 indicates that one-period lagged stock returns, the January (first quarter) effect, and the error correction term are statistically significant.

Model 5, the second stage regression for $\Delta \mathrm{I}^{10-\mathrm{yr}}$, indicates that changes in monetary policy affect changes in interest rates - the exogenous component of $\Delta \mathrm{M}_{\mathrm{t}}$ is statistically significant and positive, consistent with the hypothesis. The coefficient suggests that a 100 basis point increase in the federal funds rates corresponds with an approximate 26.8 basis point increase in 10-year Treasury yields. The estimate for $\Delta \mathrm{S}_{\mathrm{t}}$ is not robust, and the only other statistically significant variable in the second stage regression is $\mathrm{e}_{\mathrm{t}-10-\mathrm{y}}^{\mathrm{I}}$.

Finally, the second stage regression for $\Delta \mathrm{M}_{\mathrm{t}}$ suggests that stock returns and changes in Treasury yields do not affect changes in the stance of monetary policy. According to Model 6, the orthogonal components of $\Delta \mathrm{S}_{\mathrm{t}}$ and $\Delta \mathrm{I}^{10-\mathrm{yr}}$ are not statistically significant, although the coefficients have the expected signs. Rather, the regression suggests that $\Delta \psi_{\mathrm{t}}$ and $\mathrm{e}_{\mathrm{t}-1}^{\mathrm{M}}$ are statistically significant with the expected signs. ${ }^{17}$

\footnotetext{
${ }^{17}$ Results using the real effective funds rate are available on request.
} 


\subsection{Econometric Results: An Alternative Proxy for $M_{t}$ : Policy Expectations}

The nominal federal funds rate is certainly not the only possible proxy for $\mathrm{M}_{\mathrm{t}}{ }^{18}$ This issue is far from trivial - Durham (2001a, 2003) finds that the purported relation between the stance of monetary policy and stock returns is highly sensitive to proxy selection. Therefore, sturdy results should be largely insensitive to proxy selection, and the remainder of this section examines a few alternative variables.

A forward-looking measure of $\mathrm{M}_{\mathrm{t}}$ might be instructive - market participants might react not only to contemporaneous changes but also to expected changes in the stance of monetary policy. Table 6 examines the results using the spread of two-year Treasury notes, which likely incorporate near- to medium-term policy expectations, over the effective federal funds rate as a proxy for $\mathrm{M}_{\mathrm{t}}$. Neither the first nor the second stage regressions include $\mathrm{e}^{\mathrm{M}}{ }_{\mathrm{t}-1}$ among the exogenous variables, because both ADF and KPSS tests indicate that the spread is stationary given data from 1978:Q4 to 2002:Q3. ${ }^{19}$

Turning to the results, Models 4 and 5 in Table 6 suggest that the exogenous component of the change in the spread between two-year notes and the federal funds rate is not a statistically significant correlate of either stock returns or changes in 10-year Treasury yields. Also, the exogenous components of $\Delta \mathrm{S}_{\mathrm{t}}$ and $\Delta \mathrm{I}^{10 \text {-yr }}$ are not statistically significant in any second stage regression given this alternative specification.

\subsection{Econometric Results: Dichotomous Measures of the Stance of Monetary Policy}

Previous studies also use dichotomous variables that purport to distinguish restrictive versus accommodative policy. The first measure, particularly common in the literature on

\footnotetext{
${ }^{18}$ For a discussion of alternative measures of the stance of monetary policy, see Bernanke and Mihov (1995).

19 These results are available on request.
} 
monthly and quarterly stock returns, is a "tightening" dummy variable that takes a value of "1" for a quarter if the last change in the nominal target federal funds rate was an increase and a value of " 0 " if the last change was a decrease. ${ }^{20}$ Use of a dichotomous variable necessitates some changes in the econometric esimation of the first and second stage regressions. Similar to the models in Table 6 , the exogenous variables do not include an estimate for $\mathrm{e}^{\mathrm{M}-1}$, and the first and second stage equations for $\mathrm{M}_{\mathrm{t}}$, Models 3 and 6 , are probit regressions.

The results in Table 7 using the tightening dummy variable suggest that the stance of monetary policy does not affect asset prices. While Models 4 and 5 produce coefficients that have the expected sign, the exogenous component of the tightening dummy is not robust in the second stages regressions for $\Delta \mathrm{S}_{\mathrm{t}}$ and $\Delta \mathrm{I}^{10-\mathrm{yr}}{ }_{\mathrm{t}}$.

This alternative specification, however, suggests that monetary policy responds to changes in Treasury yields. Model 6 suggests that tightening episodes are more likely when the exogenous component of Treasury yields increases. Similar to the results in Tables 5 and 6 , the orthogonal component of $\Delta \mathrm{S}_{\mathrm{t}}$ is not robust in the second stages regressions for $\Delta \mathrm{I}^{10-\mathrm{yr}}{ }_{\mathrm{t}}$ or $\mathrm{M}_{\mathrm{t}}$.

The tightening dummy variable is somewhat peculiar in that the level of $\mathrm{M}_{\mathrm{t}}$ enters the short-run regressions. This is, however, consistent with many studies that test whether stock returns are lower (higher) during tightening (easing) episodes, regardless of the stage of the monetary policy cycle. But to the contrary, perhaps initial changes in the prevailing monetary policy regime are critical, as the first move in either a tightening or easing cycle possibly has a pronounced impact on asset prices.

\footnotetext{
${ }^{20}$ Despite its diminutive status as a policy tool, several studies of the effect of monetary policy on monthly and quarterly stock returns, such as Jensen and Johnson (1995) and Conover et al. (1999a, 1999b), use the discount rate, while Durham (2003) uses the federal funds rate. Given data limitations, the target federal funds discount rate tightening dummy uses the discount rate before 1986.
} 
To test this notion, Table 8 reports the results using the first difference of the tightening dummy as the proxy for $\mathrm{M}_{\mathrm{t}}$. Notably, the first difference of the dichotomous variable has three possible values - a change from easing to tightening, a change from tightening to easing, or no change in prevailing policy. Therefore, the first and second stage regressions for $\Delta \mathrm{M}_{\mathrm{t}}$, Models 3 and 6 , are multinomial probit models.

These data suggest that initial changes in the monetary policy regime also do not affect asset prices. The exogenous components of the first tightening and first easing dummy variables have the expected signs in the second stage model for $\Delta \mathrm{S}_{\mathrm{t}}$ (Model 4 , Table 8), but the estimates are not statistically significant. Also, the exogenous component of the first tightening dummy variable is perversely signed in the second stage regression for $\Delta \mathrm{I}^{10-y r}$ (Model 5), and both estimates are statistically insignificant. Finally, the exogenous components of $\Delta \mathrm{S}_{\mathrm{t}}$ and $\Delta \mathrm{I}^{10-\mathrm{yr}}{ }_{\mathrm{t}}$ are not statistically significant in any second stage regressions given this alternative specification. ${ }^{21}$

\section{Conclusions}

The preceding analyses address the existing literature on the effects of monetary policy on asset prices in two general ways. First, the estimates follow a simple error correction specification, which is particularly useful given the posited transitory effects of monetary policy. Second, the 2SLS regressions relax the assumption that stock prices, interest rates, and monetary policy are exogenous in the short-run.

In general, the error correction terms are statistically significant, which therefore suggests that the markets for equities and Treasury securities exhibit some reversion force toward equilibrium from period to period. Indeed, each of the eight estimates of $\mathrm{e}_{\mathrm{t}-1}^{\mathrm{S}}$ and $\mathrm{e}^{\mathrm{I} 10-\mathrm{yr}}{ }_{\mathrm{t}-1}$ are

\footnotetext{
${ }^{21}$ Results using dichotomous variables based on the real effective funds rate are available on request.
} 
statistically significant in both the first and second stage regressions in Tables 5-8. However, this inference ultimately rests on the fine distinction between I(1) processes and stationary series with parameter $\operatorname{break}(\mathrm{s})$.

In general, these results using data from 1978:Q4 to 2002:Q3 indicate that monetary policy has limited impact on financial asset prices at a quarterly frequency. ${ }^{22}$ The exception is the finding that the exogenous component of the nominal federal funds rate is a statistically significant determinant of 10-year Treasury yields, ceteris paribus. In addition, few data suggest that monetary policy responds to changes in asset prices, although the coefficient for the exogenous component of $\Delta \mathrm{I}^{10 \text {-yr }}$ is significant in the second stage probit model of the tightening dummy variable.

Additional research would be instructive. For example, with respect to both cointegration theory and simultaneous equation estimation, perhaps alternative econometric techniques would be useful. In addition, while data are somewhat limited, especially in the context of error correction methodology, consideration of how the effect of monetary policy on asset prices changes over time would be useful. Indeed, changes in Federal Reserve disclosure policy, particularly since 1994, have perhaps influenced how market participants react to news and expectations about monetary policy. But nonetheless, any possible estimations of the relations between monetary policy on asset prices should directly address the issue of simultaneity.

\footnotetext{
${ }^{22}$ Use of high frequency data arguably ameliorates the issue of simultaneity bias. In the very short run, perhaps monetary policy announcements are truly exogenous shocks to asset prices, at least for the immediate period bracketing the news about policy. But use of short-run data is somewhat limited in the context of monetary policy transmission, which purportedly works with sufficiently long lags - the initial policy reaction, however exogenous, might unwind or, simply, other market forces might dwarf the effect of policy over longer periods.
} 
Table 1: Unit Root and Mean Stationarity Tests, Stock Market Equations*

\begin{tabular}{|c|c|c|c|c|c|}
\hline$\underline{\text { Variable }}$ & $\underline{\text { Test }}$ & $\mathrm{p}$ value & $\underline{\eta_{u}}$ & $\underline{\operatorname{Lags}}$ & Obs. \\
\hline \multirow[t]{4}{*}{ S\&P $500(\log )$} & $\mathrm{ADF}$ & 0.593 & & 8 & 96 \\
\hline & KPSS & & 1.133 & 8 & 96 \\
\hline & $\mathrm{ADF}$ & 0.711 & & 1 & 96 \\
\hline & KPSS & & 4.748 & 1 & 96 \\
\hline \multirow[t]{4}{*}{$\Delta \mathrm{S} \& \mathrm{P} 500(\log )$} & $\mathrm{ADF}$ & 0.809 & & 8 & 96 \\
\hline & KPSS & & 0.146 & 8 & 96 \\
\hline & $\mathrm{ADF}$ & 0.000 & & 1 & 96 \\
\hline & KPSS & & 0.190 & 1 & 96 \\
\hline \multirow[t]{4}{*}{ Earnings per Share (1-year Forward, S\&P 500, log) } & $\mathrm{ADF}$ & 0.920 & & 8 & 88 \\
\hline & KPSS & & 1.144 & 8 & 96 \\
\hline & $\mathrm{ADF}$ & 0.740 & & 1 & 95 \\
\hline & KPSS & & 4.752 & 1 & 96 \\
\hline \multirow[t]{4}{*}{$\Delta$ Earnings per Share (1-year Forward, S\&P 500, log) } & $\mathrm{ADF}$ & 0.011 & & 8 & 87 \\
\hline & KPSS & & 0.076 & 8 & 96 \\
\hline & $\mathrm{ADF}$ & 0.001 & & 1 & 94 \\
\hline & KPSS & & 0.129 & 1 & 96 \\
\hline \multirow[t]{4}{*}{ 10-year Treasury Yield } & $\mathrm{ADF}$ & 0.843 & & 8 & 96 \\
\hline & KPSS & & 0.984 & 8 & 96 \\
\hline & $\mathrm{ADF}$ & 0.713 & & 1 & 96 \\
\hline & KPSS & & 3.868 & 1 & 96 \\
\hline \multirow[t]{4}{*}{$\Delta 10$-year Treasury Yield } & $\mathrm{ADF}$ & 0.010 & & 8 & 96 \\
\hline & KPSS & & 0.147 & 8 & 96 \\
\hline & $\mathrm{ADF}$ & 0.000 & & 1 & 96 \\
\hline & KPSS & & 0.138 & 1 & 96 \\
\hline \multirow[t]{4}{*}{$\mathrm{e}^{\mathrm{s}} \mathrm{t}_{\mathrm{t}}$} & $\mathrm{ADF}$ & 0.037 & & 8 & 87 \\
\hline & KPSS & & 0.061 & 8 & 96 \\
\hline & $\mathrm{ADF}$ & 0.079 & & 1 & 94 \\
\hline & KPSS & & 0.154 & 1 & 96 \\
\hline
\end{tabular}

*KPSS critical values of $\eta_{u}$ for $\mathrm{H} 0$ of level stationarity are 0.347 (10 percent), 0.463 (5 percent), and 0.739 (1 percent). 
Table 2: Unit Root and Mean Stationarity Tests: Treasury Yield Equations*

\begin{tabular}{|c|c|c|c|c|c|}
\hline$\underline{\text { Variable }}$ & $\underline{\text { Test }}$ & $\mathrm{p}$ value & $\underline{\eta}_{\underline{u}}$ & $\underline{\text { Lags }}$ & Obs. \\
\hline \multirow[t]{4}{*}{ Three-year Average Quarterly Inflation Rate (CPI) (\%) } & $\mathrm{ADF}$ & 0.657 & & 8 & 96 \\
\hline & KPSS & & 0.753 & 8 & 96 \\
\hline & ADF & 0.441 & & 1 & 96 \\
\hline & KPSS & & 3.088 & 1 & 96 \\
\hline \multirow[t]{4}{*}{$\Delta$ Three-year Average Quarterly Inflation Rate (CPI) (\%) } & $\mathrm{ADF}$ & 0.001 & & 8 & 96 \\
\hline & KPSS & & 0.072 & 8 & 96 \\
\hline & $\mathrm{ADF}$ & 0.021 & & 1 & 96 \\
\hline & KPSS & & 0.211 & 1 & 96 \\
\hline \multirow[t]{4}{*}{ Real (Effective) Federal Funds Rate } & $\mathrm{ADF}$ & 0.131 & & 8 & 96 \\
\hline & KPSS & & 0.261 & 8 & 96 \\
\hline & $\mathrm{ADF}$ & 0.026 & & 1 & 96 \\
\hline & KPSS & & 0.744 & 1 & 96 \\
\hline \multirow[t]{4}{*}{$\Delta$ Real (Effective) Federal Funds Rate } & $\mathrm{ADF}$ & 0.010 & & 8 & 96 \\
\hline & KPSS & & 0.177 & 8 & 96 \\
\hline & $\mathrm{ADF}$ & 0.000 & & 1 & 96 \\
\hline & KPSS & & 0.092 & 1 & 96 \\
\hline \multirow[t]{4}{*}{ Marketable Federal Interest-bearing Debt to GDP (\%) } & $\mathrm{ADF}$ & 0.180 & & 8 & 96 \\
\hline & KPSS & & 0.644 & 8 & 96 \\
\hline & $\mathrm{ADF}$ & 0.411 & & 1 & 96 \\
\hline & KPSS & & 2.665 & 1 & 96 \\
\hline \multirow[t]{4}{*}{$\Delta$ Marketable Federal Interest-bearing Debt to GDP (\%) } & $\mathrm{ADF}$ & 0.289 & & 8 & 96 \\
\hline & KPSS & & 0.530 & 8 & 96 \\
\hline & $\mathrm{ADF}$ & 0.017 & & 1 & 96 \\
\hline & KPSS & & 1.729 & 1 & 96 \\
\hline \multirow[t]{4}{*}{ Net Exports to GDP (\%) } & $\mathrm{ADF}$ & 0.501 & & 8 & 96 \\
\hline & KPSS & & 0.445 & 8 & 96 \\
\hline & $\mathrm{ADF}$ & 0.872 & & 1 & 96 \\
\hline & KPSS & & 1.673 & 1 & 96 \\
\hline \multirow[t]{4}{*}{$\Delta$ Net Exports to GDP $(\%)$} & $\mathrm{ADF}$ & 0.104 & & 8 & 96 \\
\hline & KPSS & & 0.139 & 8 & 96 \\
\hline & $\mathrm{ADF}$ & 0.000 & & 1 & 96 \\
\hline & KPSS & & 0.172 & 1 & 96 \\
\hline \multirow[t]{4}{*}{$e_{t}^{I 10-y r}$} & $\mathrm{ADF}$ & 0.064 & & 8 & 87 \\
\hline & KPSS & & 0.093 & 8 & 96 \\
\hline & $\mathrm{ADF}$ & 0.016 & & 1 & 94 \\
\hline & KPSS & & 0.186 & 1 & 96 \\
\hline
\end{tabular}

*KPSS critical values of $\eta_{\mathrm{u}}$ for $\mathrm{H} 0$ of level stationarity are 0.347 (10 percent), 0.463 (5 percent), and 0.739 ( 1 percent). 
Table 3: Unit Root and Mean Stationarity Tests: Taylor Rule Equations*

\begin{tabular}{|c|c|c|c|c|c|}
\hline$\underline{\text { Variable }}$ & $\underline{\text { Test }}$ & $\mathrm{p}$ value & $\underline{\eta_{\underline{u}}}$ & $\underline{\text { Lags }}$ & Obs. \\
\hline \multirow[t]{4}{*}{ (Effective) Federal Funds Rate } & $\mathrm{ADF}$ & 0.610 & & 8 & 96 \\
\hline & KPSS & & 0.880 & 8 & 96 \\
\hline & $\mathrm{ADF}$ & 0.548 & & 1 & 96 \\
\hline & KPSS & & 3.273 & 1 & 96 \\
\hline \multirow[t]{4}{*}{$\Delta$ (Effective) Federal Funds Rate } & $\mathrm{ADF}$ & 0.033 & & 8 & 96 \\
\hline & KPSS & & 0.094 & 8 & 96 \\
\hline & $\mathrm{ADF}$ & 0.000 & & 1 & 96 \\
\hline & KPSS & & 0.085 & 1 & 96 \\
\hline \multirow[t]{4}{*}{ Output Gap (Nominal) } & $\mathrm{ADF}$ & 0.191 & & 8 & 96 \\
\hline & KPSS & & 0.282 & 8 & 96 \\
\hline & $\mathrm{ADF}$ & 0.113 & & 1 & 96 \\
\hline & KPSS & & 0.930 & 1 & 96 \\
\hline \multirow[t]{4}{*}{$\Delta$ Output Gap (Nominal) } & $\mathrm{ADF}$ & 0.027 & & 8 & 96 \\
\hline & KPSS & & 0.088 & 8 & 96 \\
\hline & $\mathrm{ADF}$ & 0.000 & & 1 & 96 \\
\hline & KPSS & & 0.125 & 1 & 96 \\
\hline \multirow[t]{4}{*}{$\mathrm{e}^{\mathrm{M}}{ }_{\mathrm{t}}$} & $\mathrm{ADF}$ & 0.573 & & 8 & 87 \\
\hline & KPSS & & 0.266 & 8 & 96 \\
\hline & $\mathrm{ADF}$ & 0.034 & & 1 & 94 \\
\hline & KPSS & & 0.780 & 1 & 96 \\
\hline
\end{tabular}

*KPSS critical values of $\eta_{u}$ for $\mathrm{H} 0$ of level stationarity are 0.347 (10 percent), 0.463 (5 percent), and 0.739 (1 percent). 
Table 4: Cointegrating Regressions

Stock Prices, Treasury Yields, and the Effective Federal Funds Rate

Dependent Variable:

Independent Variables

Earnings per Share (1-year Forward, S\&P 500, log)

10-year Treasury Yield

Three-year Average Quarterly Inflation Rate (CPI) (\%)

Marketable Federal Interest-bearing Debt to GDP (\%)

Net Exports to GDP (\%)

Output Gap (Nominal)

Constant

Observations

R-squared

Standard errors in parentheses

+ significant at $10 \% ;{ }^{*}$ significant at $5 \% ;{ }^{* *}$ significant at $1 \%$
(1)

$\mathrm{S}_{\mathrm{t}}$

$\mathrm{I}_{\mathrm{t}}^{10-\mathrm{yr}}$

$\mathrm{M}_{\mathrm{t}}$

$\begin{array}{ccc}1.477 & -2.648 & \\ (0.044)^{* *} & (0.400)^{* *} & \\ -0.065 & & \\ (0.008)^{* *} & & \\ & 0.884 & (0.399 \\ & (0.142)^{* *} & \\ & 0.113 & \\ & (0.042)^{* *} & \\ & -0.903 & \\ & (0.233)^{* *} & 0.686 \\ & & (0.086)^{* *} \\ 1.466 & 7.757 & 1.595 \\ (0.202)^{* *} & (2.742)^{* *} & (0.321)^{* *} \\ & & 96 \\ 96 & 96 & 0.82\end{array}$


Table 5: Two-Stage Least Squares Regressions: Stock Prices, Treasury Yields, and Changes in (Effective) Federal Funds Rates

Dependent Variable:
Independent Variables
$\Delta$ Earnings per Share (1-year Forward, S\&P 500, log)
One-quarter Lagged S\&P 500 Return
Second-4th-quarter Lagged S\&P 500 Return
Fifth-8th-quarter Lagged S\&P 500 Return
First Quarter Dummy (January Effect)
Third Quarter Dummy (September Effect)
$\mathrm{e}_{\mathrm{t}-1}^{\mathrm{s}}$

$\Delta$ Three-year Average Quarterly Inflation Rate (CPI) (\%)

$\Delta$ Marketable Federal Interest-bearing Debt to GDP (\%)

$\Delta$ Net Exports to GDP (\%)

$\mathrm{e}_{\mathrm{I}-1}^{\mathrm{I10}-\mathrm{yr}}$

$\Delta$ Output Gap (Nominal)

Lagged $\Delta$ (Effective) Federal Funds Rate

$e^{M}{ }_{t-1}$

Exogenous Component: $\Delta \mathrm{S}_{\mathrm{t}}$

Exogenous Component: $\Delta \mathrm{I}^{10-\mathrm{yr}}{ }_{\mathrm{t}}$

Exogenous Component: $\Delta$ (Effective) Federal Funds Rate

Constant

Observations

R-squared
First Stage Regressions:

$\begin{array}{cc}(1) & (2) \\ \Delta \mathrm{S}_{\mathrm{t}} & \Delta \mathrm{I}^{10-\mathrm{yr}}{ }_{\mathrm{t}} \\ & \\ & \\ & \\ 0.239 & 3.501 \\ (0.278) & (2.797) \\ 0.300 & 0.086 \\ (0.118)^{*} & (1.183) \\ 0.231 & 0.484 \\ (0.184) & (1.850) \\ 0.174 & 3.464 \\ (0.227) & (2.281) \\ 0.025 & 0.128 \\ (0.015)+ & (0.148) \\ -0.001 & -0.001 \\ (0.014) & (0.143) \\ -0.192 & -0.690 \\ (0.064)^{* *} & (0.645) \\ -0.012 & 0.438 \\ (0.025) & (0.256)+ \\ -0.005 & -0.067 \\ (0.012) & (0.121) \\ 0.003 & -0.476 \\ (0.026) & (0.257)+ \\ -0.003 & -0.157 \\ (0.007) & (0.074)^{*} \\ -0.003 & 0.284 \\ (0.011) & (0.109)^{*} \\ -0.012 & -0.006 \\ (0.006)+ & (0.064) \\ 0.006 & -0.006 \\ (0.006) & (0.063) \\ & \end{array}$

(0)

$-0.005$

(0.013)

95
0.26
(3)

$\Delta \mathrm{M}_{\mathrm{t}}$

6.818

(4.569)

2.326

(1.933)

0.413

(3.022)

3.970

(3.726)

0.107

$(0.243)$

$-0.133$

(0.234)

$-1.301$

(1.053)

0.801

$(0.418)+$

0.107

$(0.197)$

$-0.430$

(0.420)

0.146

$(0.120)$

0.690

$(0.178)^{* *}$

0.006

(0.105)

$-0.309$

$(0.103)^{* *}$

$-0.217$

(0.129)+

95

0.33

95

0.42
Second Stage Regressions:

$\begin{array}{ccc}(4) & (6) & (7) \\ \Delta \mathrm{S}_{\mathrm{t}} & \Delta \mathrm{I}^{10-\mathrm{yr}}{ }_{\mathrm{t}} & \Delta \mathrm{M}_{\mathrm{t}}\end{array}$

$\Delta \mathrm{M}_{\mathrm{t}}$

$\begin{array}{cc}0.183 & 1.294 \\ (0.295) & (2.806) \\ 0.373 & \\ (0.113)^{* *} & \\ 0.223 & \end{array}$

(0.175)

0.211

(0.197)

0.025

$(0.015)+$

$-0.004$

(0.014)

$-0.195$

$(0.060)^{* *}$

$\begin{array}{cc}0.069 & 0.621 \\ (0.197) & (0.395) \\ -0.153 & \end{array}$

$-0.153$

(0.103)

$-0.199$

(0.241)

$-0.117$

$(0.051)^{*}$

0.656

$(0.241)^{* *}$

0.128

(0.115)

$-0.284$

$(0.103)^{* *}$

$0.925 \quad 6.207$

(2.018) (3.959)

0.093

(0.574)

(0.031)

$-0.010$

(0.017)

$-0.006$

(0.013)

0.268

$(0.117)^{*}$

$-0.054 \quad-0.154$

(0.092)

(0.136) 
Table 6: Two-Stage Least Squares Regressions: Stock Prices, Treasury Yields, and Changes in 2-Year Treasury Spread over Federal Funds Rates

Dependent Variable:

Independent Variables

$\Delta$ Earnings per Share (1-year Forward, S\&P 500, log)

One-quarter Lagged S\&P 500 Return

Second-4th-quarter Lagged S\&P 500 Return

Fifth-8th-quarter Lagged S\&P 500 Return

First Quarter Dummy (January Effect)

Third Quarter Dummy (September Effect)

$e^{S}{ }_{t-1}$

$\Delta$ Three-year Average Quarterly Inflation Rate (CPI) (\%)

$\Delta$ Marketable Federal Interest-bearing Debt to GDP $(\%)$

$\Delta$ Net Exports to GDP (\%)

$\mathrm{e}_{\mathrm{I}-\mathrm{I} 0-\mathrm{yr}}$

$\Delta$ Output Gap (Nominal)

Lagged $\Delta$ 2-year Treasury minus Federal Funds Rate

Exogenous Component: $\Delta \mathrm{S}_{\mathrm{t}}$

Exogenous Component: $\Delta \mathrm{I}^{10-\mathrm{yr}}{ }_{\mathrm{t}}$

Exogenous Component: $\Delta$ 2-year Treasury minus Federal Funds Rate

Constant

Observations

R-squared

Standard errors in parentheses

+ significant at $10 \%$; $*$ significant at $5 \%$; * significant at $1 \%$

First Stage Regressions:

(1)

$\Delta \mathrm{S}_{\mathrm{t}}$

(0.267)

0.357

$(0.115)^{* *}$

0.247

$(0.181)$

0.148

$(0.229)$

0.024

$(0.015)$

$-0.000$

(0.014)

$-0.194$

$(0.065)^{* *}$

$-0.028$

(0.024)

$-0.005$

(0.012)

0.022

(0.023)

0.001

(0.005)

$-0.005$

(0.011)

0.006

(0.009)

(2)

(3)

$\Delta \mathrm{I}_{\mathrm{t}}^{10-\mathrm{yr}}$

$\Delta \mathrm{M}_{\mathrm{t}}$

(0.009)

$-0.002$

(0.013)

$-0.224$

(0.125)

95

0.23

$(0.234) *$

$-0.067$

(0.117)

$-0.468$

$(0.222)^{*}$

$-0.163$

$(0.053)^{* *}$

0.305

$(0.106)^{* *}$

0.108

(0.087)

95

0.34

95

0.14
Second Stage Regressions:

(4) (6)

(7)

$\Delta \mathrm{S}_{\mathrm{t}} \quad \Delta \mathrm{I}^{10-\mathrm{yr}}{ }_{\mathrm{t}}$

$\Delta \mathrm{M}_{\mathrm{t}}$

$0.109 \quad 2.806$

(0.301) (2.805)

0.358

$(0.114)^{* *}$

0.234

(0.179)

0.216

(0.201)

0.025

(0.015)

$-0.002$

(0.015)

$-0.187$

$(0.059)^{* *}$

$0.073 \quad-0.505$

$\begin{array}{ll}(0.212) & (0.295)+\end{array}$

$-0.245$

$(0.104)^{*}$

$-0.339$

(0.239)

$-0.170$

$(0.054)^{* *}$

$-0.257$

(0.160)

$-0.252$

$(0.111)^{*}$

$1.942-1.719$

(2.183) (2.587)

$-0.013$

(0.020)

0.002

(0.030)

$-0.005$

(0.013)

(0.160)
95

0.21
0.164

(0.297)

$-0.392$

(0.303)

$-0.114$

(0.093)

0.026

(0.095)

95

0.27
95

0.08 
Table 7: Two-Stage Least Squares Regressions: Stock Prices, Treasury Yields, and the Monetary Policy Tightening Dummy

Dependent Variable:
Independent Variables
$\Delta$ Earnings per Share (1-year Forward, S\&P 500, log)
One-quarter Lagged S\&P 500 Return
Second-4th-quarter Lagged S\&P 500 Return
Fifth-8th-quarter Lagged S\&P 500 Return
First Quarter Dummy (January Effect)
Third Quarter Dummy (September Effect)
$\mathrm{e}_{\mathrm{t}-1}^{\mathrm{s}}$

$\Delta$ Three-year Average Quarterly Inflation Rate (CPI) (\%)

$\Delta$ Marketable Federal Interest-bearing Debt to GDP (\%)

$\Delta$ Net Exports to GDP (\%)

$\mathrm{e}^{\mathrm{I110-yr}} \mathrm{t}-1$

$\Delta$ Output Gap (Nominal)

Lagged Tightening Dummy

Exogenous Component: $\Delta \mathrm{S}_{\mathrm{t}}$

Exogenous Component: $\Delta \mathrm{I}^{10-y r}$

Exogenous Component: Tightening Dummy

Constant

Observations

R-squared

Standard errors in parentheses

+ significant at $10 \%$; * significant at $5 \%$; * significant at $1 \%$
First Stage Regressions:

$\begin{array}{cc}(1) & (2) \\ & \\ \Delta \mathrm{S}_{\mathrm{t}} & \Delta \mathrm{I}^{10-\mathrm{yr}}{ }_{\mathrm{t}} \\ & \\ & \\ & \\ 0.193 & 3.450 \\ (0.288) & (2.856) \\ 0.346 & 0.079 \\ (0.114)^{* *} & (1.132) \\ 0.229 & 0.421 \\ (0.180) & (1.778) \\ 0.152 & 3.442 \\ (0.228) & (2.262) \\ 0.024 & 0.128 \\ (0.015) & (0.147) \\ 0.000 & -0.002 \\ (0.014) & (0.143) \\ -0.184 & -0.698 \\ (0.065)^{* *} & (0.643) \\ -0.026 & 0.429 \\ (0.024) & (0.237)^{+} \\ -0.009 & -0.068 \\ (0.013) & (0.125) \\ 0.021 & -0.481 \\ (0.023) & (0.224)^{*} \\ 0.002 & -0.163 \\ (0.006) & (0.057)^{* *} \\ -0.008 & 0.281 \\ (0.011) & (0.107)^{*} \\ -0.015 & 0.007 \\ (0.016) & (0.157) \\ & \\ & \end{array}$

(3)

$\mathrm{M}_{\mathrm{t}}$

$M_{\mathrm{t}}$ Second Stage Regressions:

(4)

(4)

(6)

(7)

$\Delta \mathrm{S}_{\mathrm{t}}$

$\Delta \mathrm{I}^{10-\mathrm{yr}}$

$\mathrm{M}_{\mathrm{t}}$

\begin{tabular}{c|cc}
65.898 & 0.447 & 0.749 \\
$(25.116)^{* *}$ & $(0.372)$ & $(3.622)$ \\
2.624 & 0.360 &
\end{tabular}

\begin{tabular}{l|l}
$(5.137)$ & $(0.110)^{* *}$
\end{tabular}

$\begin{array}{ll}-11.102 & 0.207\end{array}$

$(9.084) \quad(0.174)$

$\begin{array}{ll}37.578 & 0.360\end{array}$

$(18.331)^{*} \quad(0.222)$

$\begin{array}{ll}0.349 & 0.025\end{array}$

$\begin{array}{ll}(0.719) & (0.015)\end{array}$

$\begin{array}{ll}-1.405 & -0.006\end{array}$

(0.910) (0.014)

$-3.412-0.196$

(4.410) $(0.059)^{* *}$

3.117

(2.405)

$-0.220$

(0.834)

$-3.666$

$(1.945)+$

$-0.591$

$(0.405)$

1.532

(0.980)

4.068

$(1.463)^{* *}$

$\begin{array}{ccc} & & \\ & & \\ & & \\ 0.003 & -0.217 & -4.227 \\ (0.014) & (0.135) & (1.379)^{* *}\end{array}$

95

0.33

(0.003) 
Table 8: Two-Stage Least Squares Regressions: Stock Prices, Treasury Yields, and the First Difference of the Tightening Dummy

First Stage Regressions:

$(1)$

Dependent Variables:

Independent Variables

$\Delta$ Earnings per Share (1-year Forward, S\&P 500, log)

One-quarter Lagged S\&P 500 Return

Second-4th-quarter Lagged S\&P 500 Return

Fifth-8th-quarter Lagged S\&P 500 Return

First Quarter Dummy (January Effect)

Third Quarter Dummy (September Effect)

$\mathrm{e}_{\mathrm{t}-1}^{\mathrm{S}}$

$\Delta$ Three-year Average Quarterly Inflation Rate (CPI) (\%)

$\Delta$ Marketable Federal Interest-bearing Debt to GDP (\%)

$\Delta$ Net Exports to GDP (\%)

$\mathrm{e}^{\mathrm{I1} 10-\mathrm{yr}} \mathrm{t}-1$

$\Delta$ Output Gap (Nominal)

Lagged $\Delta$ Tightening Dummy

Exogenous Component: $\Delta \mathrm{S}_{\mathrm{t}}$

Exogenous Component: $\Delta \mathrm{I}^{10-y r}$

Exogenous Component: First Tightening

Exogenous Component: First Easing

Constant

Observations

R-squared
$-0.004$

$(0.013)$

$-0.224$

$(0.127)+$

$\begin{array}{cc}95 & 95 \\ 0.24 & 0.34\end{array}$

0.24

(2)

$\Delta \mathbf{I}^{10-y r}{ }_{\mathrm{t}}$

0.122

$(0.266)$

$(0.114)^{* *}$

0.246

(0.179)

0.125

(0.229)

0.026
$(0.015)+$

0.001

(0.014)

$(0.065)^{*}$

$-0.030$

(0.023)

$-0.004$

0.020

(0.023)

0.001

$-0.007$

(0.011)

$(0.008)$

3.727

(2.633)

0.059

(1.128)

0.470

(1.773)

3.307

(2.264)

0.150

(0.150)

0.011

$(0.143)$

$-0.666$

(0.639)

0.438

$(0.232)+$

$-0.067$

(0.118)

$-0.490$

$(0.223)^{*}$

$-0.158$

$(0.054)^{* *}$

0.274

$(0.106)^{*}$

0.055

(0.081)

95

(3)

$\Delta \mathrm{M}_{\mathrm{t}}$

(5.610)

2.666

(2.369)

$-5.605$

(3.738)

5.494

(4.911)

0.418

(0.311)

0.423

(0.307)

0.905

(1.357)

1.128

(0.505)*

0.186

(0.247)

0.545

(0.476)

$-0.071$

(0.114)

0.167

(0.227)

$-0.922$

$(0.188)^{* * *}$
$-0.018$

$(0.020)$

$-0.047$

$(0.121)$

0.009

$(0.120)$

0.002

$(0.083)$

95
0.23

Second Stage Regressions:

(4)

$\Delta \mathrm{I}^{10-\mathrm{yr}}{ }_{\mathrm{t}}$

(7)

$\Delta \mathrm{M}_{\mathrm{t}}$

$0.218 \quad 4.862$

0.372

$(0.112)^{* *}$

0.198
$(0.174)$

0.245

$(0.197)$

$0.016)^{*}$

0.005

$-0.187$

$(0.059)^{* *}$

0.158

$(0.210)$

$-0.210$

$(0.104)^{*}$

$-0.428$

$(0.225)+$

$-0.144$

$(0.050)^{* *}$

$-0.241$

$(0.199)$

$-0.887$

$(0.176)^{* *}$

2.725

(2.141)

0.904

(1.973)

0.504

$(0.398)$

$-1.448$

(1.203)

$-1.442$

(1.186)

0.822

(0.807)

95

0.27

Standard errors in parentheses

+ significant at $10 \%$; $*$ significant at $5 \%$; * significant at $1 \%$ 


\section{References}

Bernanke, Ben S. and Ilian Mihov, 1995, "Measuring Monetary Policy,” NBER Working Paper Series No. 5145.

Campbell, John Y. and P. Perron, 1991, "Pitfalls and Opportunities: What Macro-economists Should Know about Unit Roots," in O. J. Blanchard and S. Fischer, eds., NBER Macroeconomics Annual, 1991, Cambridge MA: MIT Press, 141-200.

Campbell, John Y. and Robert J. Shiller, 1987, "Cointegration and Tests of Present Value Models," Journal of Political Economy, vol. 95, 1062-1088.

Conover, C. Mitchell, Gerald R. Jensen, and Robert R. Johnson, 1999a, "Monetary

Environments and International Stock Returns," Journal of Banking and Finance, vol. 23, 13571381.

Conover, C. Mitchell, Gerald R. Jensen, and Robert R. Johnson, 1999b, "Monetary Conditions and International Investing," Financial Analysts Journal, 1357-1381.

Cook, Timothy, and Thomas Hahn, 1988, "The Information Content of Discount Rate Annoucements and Their Effect on Market Interest Rates," Journal of Money, Credit, and Banking, vol. 20 no. 2 (May), 167-180.

De Bondt, W. R. M., and R. Thaler, 1985, “Does the Stock Market Overreact?” Journal of Finance 40, 793-805.

Durham, J. Benson, 2003, "Should Equity Investors 'Fight the Central Bank'?: The Effect of Monetary Policy on Stock Market Returns," Financial Analysts Journal, forthcoming.

Durham, J. Benson, 2001a, "The Effect of Monetary Policy on Monthly and Quarterly Stock Market Returns: Cross-Country Evidence and Sensitivity Analyses," Finance and Economic Discussion Papers Series No. 42, Federal Reserve Board.

Durham, J. Benson, 2001b, "Sensitivity Analyses of Anomalies in Developed Stock Markets," Journal of Banking and Finance, vol. 25 (August 2001), pp. 1503-1541.

Engle, R. F. and C.W.J. Granger, 1987, "Cointegration and Error Correction: Representation, Estimation and Testing," Econometrica, vol. 55, pp. 251-276.

Granger, Clive W. J., 1986, "Developments in the Study of Cointegrated Economic Variables," Oxford Bulletin of Economics and Statistics, vol. 48 no. 3, 213-228.

Harasty, Hélène, and Jacques Roulet, 2000, "Modeling Stock Market Returns: An Error Correction Model," Journal of Portfolio Management, vol. 26 no. 2 (Winter), 33-46. 
Haugen, R. A. and Lakonishok, 1987, The Incredible January Effect (Irwin: Homewood, Illinois).

Howe, Howard and Charles Pigott, 1991-1992, "Determinants of Long-Term Interest Rates: An Empirical Study of Several Industrial Countries," Federal Reserve Bank of New York Quarterly Review, (Winter), 12-28.

Jegadeesh, N., 1990, "Evidence of Predictable Behavior of Security Returns," Journal of Finance, vol. 45, 881-98.

Jensen, Gerald R. and Robert R. Johnson, 1995, "Discount Rate Changes and Security Returns in the U.S., 1962-1991," Journal of Banking and Finance, vol. 19, 79-95.

Jensen, Gerald R., Jeffry M. Mercer, and Robert R. Johnson, 1996, "Business Conditions, Monetary Policy, and Expected Security Returns," Journal of Financial Economics, vol. 40, 213-237.

Johansen, S., 1988, "Statistical Analysis of Cointegrating Vectors," Journal of Economic Dynamics and Control, vol. 12, 1-14.

Johansen, S. and K. Juselius, "Maximum-Likelihood Estimation and Inference on Cointegration - With Applications to the Demand for Money," Oxford Bulletin of Economics and Statistics, vol $52,169-210$.

Kwiatkowski, Dennis, Peter C. B. Phillips, Peter Schmidt, and Yoncheol Shin, 1992, “Testing the Null Hypothesis of Stationarity Against the Alternative of a Unit Root: How Sure Are We that Economic Time Series have a Unit Root?" Journal of Econometrics, vol. 54 (OctoberDecember), 159-178.

Mehra, Yash P., 1994, “An Error-Correction Model of the Long-Term Bond Rate," Federal Reserve Bank of Richmond Economic Quarterly, vol. 80, no. 4 (Fall), 49-68.

Perron, Pierre, 1989, "The Great Crash, the Oil Price Shock, and the Unit Root Hypothesis," Econometrica, vol. 57 no. 6 (November), 1361-1401.

Perron, Pierre, 1997, "Further Evidence on Breaking Trend Functions in Macroeconomic Variables," Journal of Econometrics, vol. 80, 355-385.

Sargent, Thomas J., 1969, "Commodity Price Expectations and the Interest Rate," Quarterly Journal of Economics, vol. 83 (February), 127-140.

Siegel, Jeremy, 1998, Stocks for the Long-Run: The Definitive Guide to Financial Market Returns and Long-Term Investment Strategies (New York: McGraw-Hill).

Smirlock, Michael and Jess Yawitz, 1985, "Asset Returns, Discount Rate Changes, and Market Efficiency," Journal of Finance, vol. 40 no. 4 (September), 1141-1158. 
Taylor, John, 1993, "Discretion versus Policy Rules in Practice," Carnegie-Rochester Conference Series on Public Policy, vol. 39, 195-214.

Waud, R., 1970, "Public Interpretation of Federal Reserve Discount Rate Changes: Evidence on the "Announcement Effect,"” Econometrica, vol. 38, 231-250. 